\title{
UTILIZATION OF COCOYAM IN RURAL HOUSEHOLDS IN SOUTHWESTERN NIGERIA
}

\section{Agbelemoge A*1}

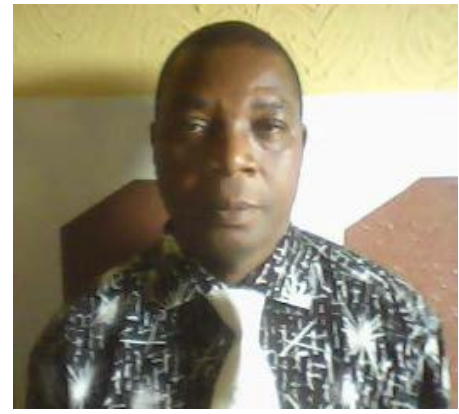

Adeyanju Agbelemoge

*Corresponding author email: adeyanjuagbelemoge@yahoo.com

${ }^{1}$ Dept of Agric Extension \& Rural Sociology, College of Agricultural Sciences Ayetoro Yewa Campus, Olabisi Onabanjo University AgoIwoye, Nigeria 


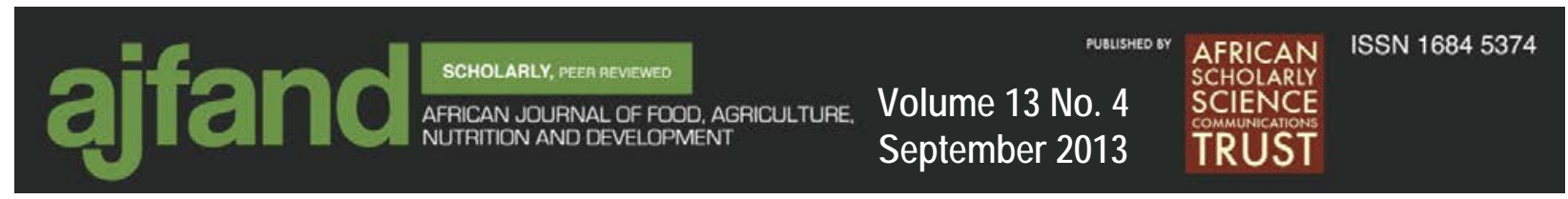

\section{ABSTRACT}

Cocoyam is a traditional crop and a cultural foodstuff in Nigeria. It has not received much research attention in spite of its great adaptability to varying farming systems and its nutritive and commercial food values. The crop is a yam substitute that occupies an inferior food status in the study area. It is mainly cultivated by women and in most cases planted as an intercrop in a previously established farm. It is, therefore, regarded as a lazy man's crop and consequently a poor man's food. The aim of this study was to revive the acceptability of cocoyam as foodstuff in order to solve the food crisis, which Nigeria has been experiencing since 1978. A structured interview schedule was used to obtain information from randomly selected 322 respondents from 24 cocoyam producing communities in four states in the region: Ondo, Ekiti, Ogun and Lagos states. The question items included personal and socioeconomic characteristics of respondents and cocoyam utilization. The data were described using frequency counts, means and percentages while multiple regression analysis was used as inferential statistics to determine the relationship of the independent variables to the dependent variable. Results revealed that $64 \%$ of the respondents were males and $84 \%$ were married. Their ages ranged from 20-70 years with a mean of $44 \pm 16$ years. About $68 \%$ of them were literate with $58 \%$ of their spouses literate. They were mostly (39\%) farmers and artisans (12\%) with no secondary occupation, only $28 \%$ of the farmers produced cocoyam but almost all (97\%) of the respondents consumed cocoyam. Cocoyam was utilized in 24 different ways in three categories of unprocessed solid, processed solid and powder in the study area and utilization level was $20 \%$. The multiple regression analysis was significant at $\mathrm{p}<0.05$ and $\mathrm{R}=0.3469$, meaning that the independent variable:socio-economic characteristics had jointly accounted for $35 \%$ of cocoyam utilization level. $F$ value was 5.334. The variables that contributed positively to utilization level were producers of cocoyam, sources of cocoyam and cocoyam being brought home from journey while cosmopolitan, flexibility on food choice and decision makers on menu contributed negatively. Commercial processing of cocoyam to flour for baking, canned foods, baby food formulae and other cocoyam products are recommended to increase utilization. Farmers were advised to increase cocoyam production in the study area.

Key words: Utilization, Cocoyam, household, southwestern Nigeria 


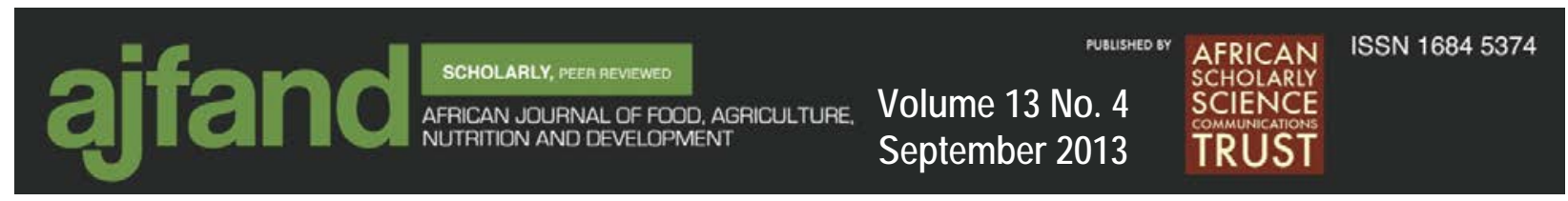

\section{INTRODUCTION}

Cocoyam (Colocasia and Xanthosoma species) is one of the major five tuber crops produced in Nigeria for local consumption alongside yam (Dioscorea spp), cassava (Manihot spp), irish potato (Solanum tuberosus) and sweet potato (Ipomea batata)[1]. Cocoyam has become a traditional crop in southern Nigeria since its introduction in 100.A.D [2]. It perfectly adapts to varying farming systems in Nigeria and Nigeria is the world's largest producer, producing an estimate as much as $40 \%$ of the world's total production [3]. As much as $56 \%$ of southwestern Nigerian farmers grow cocoyam $[4,5]$.Cocoyam has not received much attention by researchers, hence, it is in the third place after yam and cassava among the five tuber crops according to their importance as foodstuffs in southwestern Nigeria. It is essentially a yam substitute and occupies an inferior food status [6]. The crop is mainly cultivated by women and in most cases planted as an intercrop in a previously established farm. Cocoyam is grown for local consumption in Nigeria.

Nigeria has been experiencing food crises since 1978, when the rice importation bill rose to 299.63 million US dollars and the year's total food import bill amounted to 1.58 billion dollars due to neglect of the agricultural sector in favour of the oil sector [7]. The production of major agricultural commodities in the country has also decreased considerably since 1970 [8] and had since been increasing marginally and could not keep pace with the demand for these food commodities. Over 815 million people, about 14 percent of the total world population of six billion, are hungry while more than 2 billion people or 33\% suffer from malnutrition [9].

Cocoyam has a promise to solve the problem of food insecurity in Nigeria. The projections of demand and supply for cocoyam in Nigeria during the 1984-1995 review suggested a fairly bright prospect for cocoyam when compared with yam and cassava in quantitative terms [10]. Moreover, when the production efficiency of cocoyam at $42.42 \%$ doubles that of cassava (21.79\%) and yam (19.55\%), the output of cocoyam could be doubled if efforts are geared towards increasing it [11].Cocoyam is rich in carbohydrates (20-22\% starch), and crude and essential protein (2-13\%). It is exceptionally rich in ash, low in fibre and forms a fair source of oil and fat [12]. The starch grains of taro (soft cocoyam) are small and easily digestible [12]. The total carbohydrate production of taro is about $\mathbf{6 . 0}$ tonnes per hectare as compared to only about 3.0 tonnes per hectare in rice. Therefore, cocoyam produces a large quantity of starch at cheaper cost. Taro contains $2-13 \%$ protein and is rich in most of the amino acids [12]. Cocoyam with little supplements of fish protein is enough to supply all the nutritional requirements of a weaning child [12].

One of the practical means of solving hunger problems and overcoming proteinenergy malnutrition in a developing country like Nigeria is by way of increasing production and consumption of local staples of high energy content such as cocoyam [13]. It was reported that cocoyam constituted the main staple food for the people of Ijebu-north prior to the advent of the high yielding varieties of maize and 


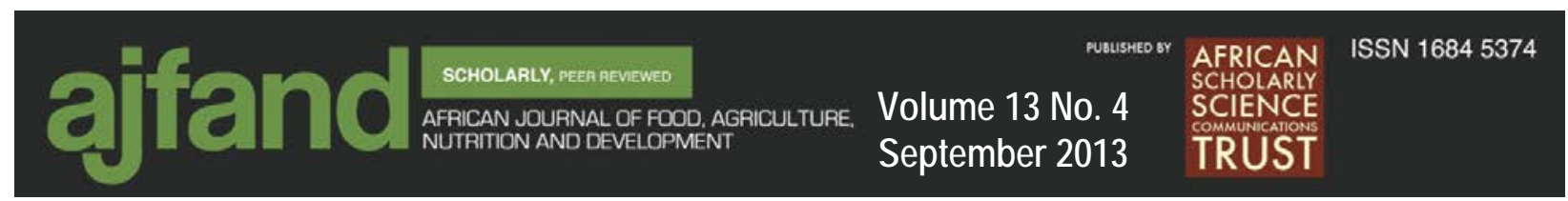

cassava[11].The introduction of the early maturing and the high yielding cassava varieties led to the relegation of cocoyam both in production and consumption. The extensive research on maize, rice and cassava had led to the decline in the acceptability of cocoyam as a food in Ijebu North Area [11].

This situation prevails in most parts of southwestern Nigeria. Hence, there is need for this study as a basis of a deliberate effort at reviving the acceptability of cocoyam as food to ameliorate the problem of food shortage and nutrition insecurity [14]. The main objective of this study was to investigate the utilization of cocoyam at household level in southwestern Nigeria. Specific objectives were to investigate the characteristics of the cocoyam consumers and producers and the pattern of cocoyam utilization in the study area.

\section{METHODOLOGY}

\section{Area of study}

The study was conducted in southwestern Nigeria. Four purposively selected states were used based on cocoyam availability. Two local government areas (LGAs) were purposively selected from each state. A random sampling technique (balloting) was employed to select three communities from each LGA, by picking from the bag one after the other without replacement after previously writing the names on paper and folding them. The states included were Ondo, Ekiti and Ogun as producing states while Lagos was included as cocoyam consuming state. The LGAs were Ondo, Ileoluji, Ekiti west, Ekiti southwest, Ijebu-north, Sagamu, Mushin and Alimoso. The communities were Yaba, Sabo, Oke-sida, Oke-alaafia, Temidire, Odokia, Aramoko, Erijiyan, Ikogosi, Igbara-odo, Ilawe, Ogotun, Ago Iwoye, Idofe, Atikori, Makun, Ajegunle, Baruwa, Okota, Atewolara, Idi-oro, Idimu, Egbeda and Ipaja.

\section{Sampling procedure}

At the community level, a systematic sampling procedure was employed at $10 \%$ intensity and a number 10 was picked hence every 10th house was selected on both sides of the street in a zig-zag manner. From each of the communities, fifteen households were randomly selected and interviewed yielding three hundred and twenty two respondents in all.

\section{Research instrument}

A structured interview schedule was developed to obtain information on personal and socio-economic characteristics and cocoyam utilization among the respondents. The interview schedule was validated and pretesting done in two non participating communities (Ijero and Ikoro) in Ijero LGA of Ekiti State. The reliability of the measuring instrument was conducted using Pearson product moment correlation coefficient $\{$ PPMC $\}$ in the split-half method and a reliability test co-efficient of $r=$ 0.64 was obtained. 


\section{Data analysis}

The data collected were coded and analyzed using the Statistical Package for Social Sciences (SPSS) [15]. Utilization level was calculated by adding up the percentages of respondents that eat, frequently eat and very frequently eat the recipes and expressed as percentage of the total respondents, while those that did not eat nor respond were regarded as non-utilizers. For the inferential statistics, the data obtained were standardized before subjecting them to multiple regression analysis.

\section{RESULTS}

\section{Demographic and socio-economic characteristics of respondents}

About $64 \%$ of the respondents were male and $84 \%$ were married with most (98\%) living with dependants in their households (Table1). Dependant' number ranged from one to thirty five with an average of eight persons in each household, while only two percent (2\%) lived alone. Respondent age ranged from 20-70 years with an average of $44 \pm 16$ years. There were $78 \%$ Christians, $14 \%$ Muslims, while one percent were not affiliated with any religion. About $62 \%$ of respondents were native to the communities sampled and most of them had lived all their lives in those communities. Only $6 \%$ had lived less than five years in their communities. Average residency was $31 \pm 22$ years. They were fairly cosmopolitan with $40 \%$ having traveled frequently to other regions outside southwestern Nigeria. About 28\% had traveled within their states, $14 \%$ had traveled to other countries and $8 \%$ had traveled only within their local government areas, while only $5 \%$ had never traveled outside their neighboring communities.

\section{Education}

About $68 \%$ of the respondents were literate, either completed primary education, had secondary, post-secondary or university education while $58 \%$ of their spouses were literate too. About $21 \%$ of respondents had no formal education same as $22 \%$ of their spouses (Table 2). The respondents did not participate in any adult education / extension class or awareness programme.

\section{Occupation}

The respondents were mostly farmers (39\%) and artisans (12\%). Other occupations included trading, civil service, teaching and business. Majority (90\%) of the respondents had no secondary occupation. The spouses`occupation was mainly (31\%) trading, civil service and business while the remaining $20 \%$ did not respond. Only $4 \%$ of the spouses had secondary occupation, which was either farming or trading. (Table 2).

\section{DISCUSSION}

\section{Cocoyam production}

About 39\% of respondents were farmers and only 28\% of them produced cocoyam. This negates the report that $56 \%$ of farmers grew cocoyam in southwestern Nigeria 


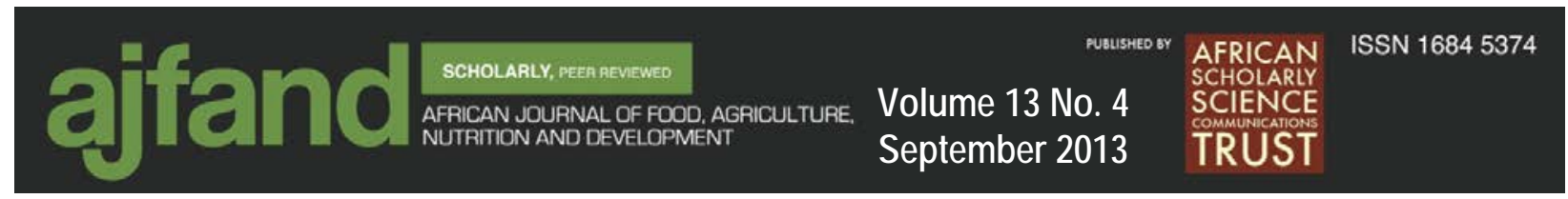

[4]. This means that cocoyam farmers are abandoning cocoyam production in southwestern Nigeria; hence cocoyam production was fairly low in the study area. In Ondo, Ekiti, Ogun and Lagos states, 28\%, 35\%, 20\% and 30\% of farmers produced cocoyam, respectively. It may be due to the cocoyam inferior food status as stated by Nyiira [16] that cocoyam is produced and consumed by low- income rural dwellers.

\section{Cocoyam consumption}

Almost all respondents (97\%) consumed cocoyam in the study area as part of family menu. The remaining 3\% would never have it eaten in their family menu, touch or allow it to be brought to their households probably due to disease scare, inferior food status or social status.

\section{Sources of cocoyam}

About $47 \%$ of cocoyam consumers produced it, $48 \%$ bought it from markets while $5 \%$ of them received their cocoyam as gifts from relatives and in-laws. This is related to a report that cocoyam is given out freely to poor relatives, sons and daughters-inlaw [16].

\section{Utilization Level}

Pounded cocoyam has the greatest utilization level in the study area, followed by cocoyam flakes, cake, fried cocoyam, porridge and flour at 27\%, 24\%, 23\%, 22\%, $21 \%$ and $21 \%$, respectively. Thus, the average utilization level was $20 \%$ for all respondents and recipes in three categories of unprocessed solid, processed solid and powder.

\section{Hypothesis testing}

There is no significant relationship between the respondents ' characteristics and their cocoyam utilization level. This hypothesis was tested with multiple regression analysis and the result is presented in Table 4. Producers of cocoyam, food brought from journeys, and sources of cocoyam have positive relationship while cosmopolite, who decides on menu and flexibility on food choice have negative relationship to utilization level.

The multiple correlation of the independent variable $\mathrm{Y}$ (utilization level) was significant at $\mathrm{R}=0.3469$, hence the independent variable respondents `characteristics had jointly accounted for only $35 \%$ of the utilization level of the respondents. The equation is: $-\quad Y=0.01-1.384 x_{1}+2.32 x_{2}-1.44 x_{3}+1.47 x_{4}-1.96 x_{5}+1.65 x_{6}$

Multiple R-square was 0.1203 meaning that the reliability of the equation is $12 \%$. F value was 5.334 with p value of 0.000003 . The relationship was significant, the null hypothesis was rejected and the alternative hypothesis accepted. The respondent characteristics were significantly related to their cocoyam utilization level. The summary of multiple regression analysis in Table 4 showed that the households that produced cocoyam utilized more cocoyam, hence one additional producer of cocoyam 


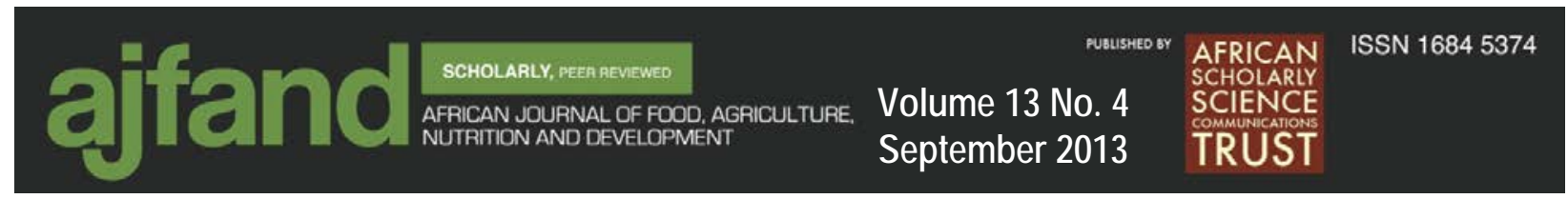

in a household resulted in an increase of more than two units on utilization scores $(+2.32)$.

Respondents who brought foodstuffs (cocoyam inclusive) from journeys had higher cocoyam utilization, an additional unit of this incidence resulted in almost one and a half increase on utilization score (+1.47). The households that were flexible on food choice had more cocoyam utilization, a unit increase in flexibility resulted in an increase of almost additional two units on utilization score $(+1.96)$.

Conversely, the more cosmopolitan the respondents were the less of cocoyam they utilized, an additional unit in cosmopolite resulted in a decrease of more than one unit of utilization score $(-1.38)$. The more the persons that made decisions on household menu, the less the household`s utilization score, an addition of one more person as decisions maker on household menu resulted in a decrease of more than one unit on utilization score (-1.44).

These results supported the theory of reasoned action that the behavioural intention to consume and utilize a foodstuff is the product of an individual`s attitude and motivation to comply with the subjective norms around the food [17].This characteristic of the respondents is identified as a determinant of cocoyam consumption as it is regarded as a poor man's food, having an inferior food status in southwestern Nigeria..

\section{CONCLUSION AND RECOMMENDATIONS}

Factors of positive relationship to cocoyam utilization were production of cocoyam, foodstuffs (cocoyam inclusive) being brought from journeys and sources of cocoyam. Conversely, cosmopolite, who decide on household menu and flexibility on households` food choice were negatively related to utilization level. Therefore, agricultural extension agencies are encouraged to:

(i) Include cocoyam in their focus and educate rural people on its production and better nutritional qualities because no awareness programme on cocoyam utilization was mounted by any agency in southwestern Nigeria

(ii) Encourage and teach farmers to cultivate cocoyam in commercial quantities and the rural people the various utilizable forms and the methods of their preparation

(iii) Commercial processing of cocoyam to flour, that can be used for baking various snacks and food items like cocoyam macaroni, rice, oats, and custard is recommended to processors for increased utilization. 
Table 1: Respondents`Demographic \& Socio-economic Characteristics

\begin{tabular}{|c|c|c|}
\hline Sex & Frequency & Percentage (\%) \\
\hline Male & 206 & 64 \\
\hline Female & 116 & 36 \\
\hline Marital Status & Frequency & Percentage (\%) \\
\hline Married & 271 & 84 \\
\hline Single & 51 & 16 \\
\hline Total & 322 & 100 \\
\hline Number of dependants & Frequency & Percentage (\%) \\
\hline One person & 07 & 02 \\
\hline Two-five persons & 97 & 30 \\
\hline Six-twelve persons & 161 & 53 \\
\hline Thirteen-thirty five persons & 34 & 11 \\
\hline No response & 10 & 03 \\
\hline Total & 322 & 100 \\
\hline Mean & 20 persons & \\
\hline Age in years & Frequency & Percentage (\%) \\
\hline Less than 20 yrs & 14 & 04 \\
\hline $20<30$ yrs & 52 & 15 \\
\hline $30<50$ yrs & 150 & 47 \\
\hline $50<70$ yrs & 68 & 21 \\
\hline No response & 22 & 07 \\
\hline Total & 322 & 100 \\
\hline Mean & 44 years & \\
\hline Religion & Frequency & Percentage (\%) \\
\hline Christian & 252 & 72 \\
\hline Muslim & 47 & 14 \\
\hline Free thinker & 14 & 4 \\
\hline Traditionalist & 4 & 1 \\
\hline No response & 5 & 1 \\
\hline Total & 322 & 100 \\
\hline
\end{tabular}


Table 2: Respondents`Occupation \& Educational Background

\begin{tabular}{|c|c|c|c|c|}
\hline Educational level & Husband & (\%) & Spouse & $(\%)$ \\
\hline None & 69 & 21 & 72 & 22 \\
\hline Incomplete primary & 22 & 07 & 33 & 10 \\
\hline Completed primary & 50 & 15 & 17 & 05 \\
\hline Incomplete secondary & 33 & 10 & 29 & 09 \\
\hline Complete secondary & 58 & 18 & 36 & 11 \\
\hline Post secondary & 44 & 14 & 31 & 10 \\
\hline University & 35 & 11 & 17 & 05 \\
\hline No response & 11 & 03 & 87 & 27 \\
\hline Total & 322 & 100 & 322 & 100 \\
\hline Occupation & Husband & $(\%)$ & Wife & $(\%)$ \\
\hline Farming & 126 & 39 & 70 & 22 \\
\hline Trading & 24 & 08 & 100 & 31 \\
\hline Artisan & 41 & 12 & 30 & 09 \\
\hline Business & 12 & 03 & 6 & 02 \\
\hline Civil service & 24 & 07 & 14 & 04 \\
\hline Teaching & 20 & 06 & 31 & 09 \\
\hline Others & 23 & 07 & - & - \\
\hline No response & 52 & 16 & 71 & 20 \\
\hline Total & 322 & 100 & 322 & 100 \\
\hline
\end{tabular}




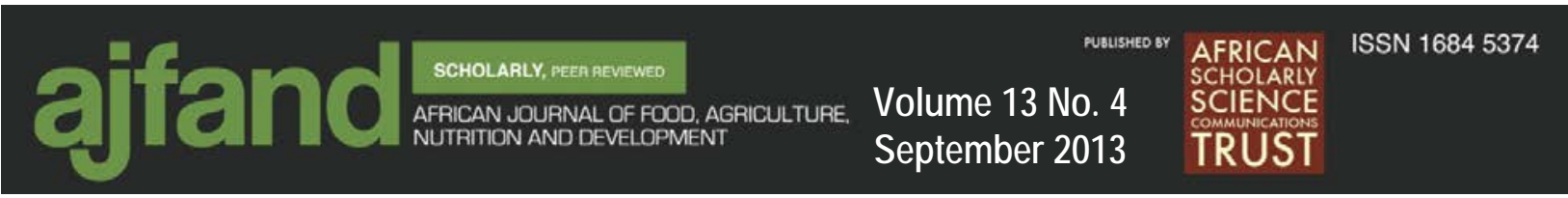

Table 3: Utilization forms and level

\begin{tabular}{|c|c|c|c|c|c|c|}
\hline Utilization forms and recipes & NE & SE & $\mathbf{E}$ & FE & VF & $\%$ \\
\hline 1. Roasted Tannia with oils & 55 & 18 & 5 & 10 & 2 & 17 \\
\hline 2. Boiled Tannia with pepper in oils & 41 & 24 & 10 & 04 & 3 & 17 \\
\hline 3. Fried Tannia with pepper in oils & 48 & 17 & 8 & 12 & 2 & 22 \\
\hline 4.Pounded Cocoyam (iyan koko) & 43 & 17 & 11 & 14 & 2 & 27 \\
\hline 5. Cocoyam flour (elubo) & 41 & 14 & 7 & 12 & 2 & 21 \\
\hline 6.Ebiripo, Godogidi or Ehpankwokwo & 43 & 17 & 5 & 11 & 1 & 17 \\
\hline 7. Cocoyam porridge (ikokore) & 44 & 14 & 9 & 9 & 3 & 21 \\
\hline 8. Cocoyam cake (ojojo) & 39 & 11 & 5 & 12 & 6 & 23 \\
\hline 9. Cocoyam flakes & 25 & 8 & 7 & 14 & 3 & 24 \\
\hline 10.Cocoyam snacks (rolls, pies) & 26 & 9 & 1 & 13 & 2 & 16 \\
\hline 11.Cocoyam confectionaries (creams,sweets) & 24 & 6 & 4 & 10 & 2 & 16 \\
\hline 12.Cocoyam condiments (soup) & 29 & 6 & 3 & 8 & 1 & 22 \\
\hline 13.Local chips (еepa) & 22 & 12 & 4 & 9 & 1 & 14 \\
\hline 14.Cocoyam bread & 24 & 5 & 7 & 7 & 0 & 14 \\
\hline 15.Cocoyam biscuits & 20 & 7 & 4 & 7 & 2 & 13 \\
\hline 16.Taro (Cocoyam) fufu & 19 & 4 & 5 & 7 & 1 & 13 \\
\hline 17.Taro poi (fermented) & 16 & 9 & 3 & 6 & 2 & 11 \\
\hline 18.Taro chips (meals, pap) & 21 & 6 & 2 & 5 & 1 & 8 \\
\hline 19.Baby food (formulae) & 21 & 5 & 1 & 4 & 2 & 7 \\
\hline 20.Taro starch & 18 & 10 & 5 & 4 & 0 & 9 \\
\hline 21.Taro flour (baking) & 16 & 6 & 6 & 5 & 1 & 12 \\
\hline 22.Leaf salad (timpa) soup & 22 & 8 & 2 & 4 & 0 & 6 \\
\hline 23.Leaf meal (powdered + groundnut) & 20 & 4 & 6 & 3 & 0 & 9 \\
\hline 24.Fallen petiole (odunrun koko) soup & 22 & 6 & 3 & 4 & 0 & 7 \\
\hline
\end{tabular}

Key : $\quad$ NE=Not eat, $\quad \mathrm{SE}=$ Seldom eat, $\mathrm{E}=$ Eat

$\mathrm{FE}=$ Frequently eat $\mathrm{VF}=$ Very frequently eat 
Table 4: Regression Results of Respondents`Characteristics and Utilization Level

\begin{tabular}{lllll}
\hline Name & Variables & B & t-value & p-level \\
Intercept & $\mathrm{a}$ & +0.010 & 0.02 & 0.988 \\
Cosmopolite & $\mathrm{X}_{1}$ & -1.384 & -2.07 & 0.040 \\
Producer of cocoyam & $\mathrm{X}_{2}$ & +2.321 & +2.69 & 0.008 \\
Who decides on menu & $\mathrm{X}_{3}$ & -1.441 & -2.14 & 0.033 \\
Food brought home from journey & $\mathrm{X}_{4}$ & +1.473 & +2.18 & 0.030 \\
Flexibility on food choice & $\mathrm{X}_{5}$ & -1.961 & -2.85 & 0.005 \\
Source of cocoyam & $\mathrm{X}_{6}$ & +1.654 & +2.28 & 0.023 \\
\hline
\end{tabular}




\section{REFERENCES}

1. Onwueme IC and WB Charles Tropical Root and Tuber Crops: Production, Perspectives and Future Prospects. FAO Plant Production and Protection. Paper 126 FAO. Rome. 1996: 6-9.

2. Mandal RC Tropical Roots and Tuber Crops. AgroBotanical Publishers. India. 1993. 392.

3. Onwueme IC A Strategy for Increasing Cocoyams: Colocasia and Xanthosoma spp in Nigeria Food Basket. Paper Presented at the $1^{\text {st }}$ National Workshop on Cocoyam in Nigeria NRCRI Umuahia 1987: 8-11.

4. Knipscheer HC and JE Wilson Cocoyam farming system in Nigeria. Proceeding of the $3^{\text {rd }}$ Symposium of ISTRC African Branch, Ibadan Nigeria 1980:247-254.

5. Utomakili JB and RG Agunbiade Cocoyam Production in Ondo State: Implication for Rural Development in: Adedoyin SF and JOY Aihonsu (Eds) Sustainable Rural Development. Proceedings of the $8^{\text {Th }}$ Annual Conference of Nigerian Rural Sociological Association. Ago-Iwoye 9th-13 ${ }^{\text {th }}$ November,1994 Segeto and Company Ijebu-Igbo. Nigeria. 1995. 95-98.

6. FOS Federal Office of Statistics Rural Agricultural Sample Survey 1986/87 Agricultural Survey Unit Lagos 35p.1996.

7 Agbelemoge A Appraisal of Upland Rice Production and Marketing in Three Towns in Ekiti West LGA of Ondo State Nigeria. An M.Sc. Dissertation at the Department of Agricultural Extension Services. University of Ibadan, Ibadan. Nigeria.120pp. 1986.

8 Central Bank of Nigeria Annual Abstract of Statistics. Central Bank of Nigeria Publications Lagos Nigeria.2000 Edition.23-4.

9 Durojaiye BO Revolving Nigeria's Food Question: The Dreams and the Dilemma $21^{\text {st }}$ Inaugural Lecture of Olabisi Onabanjo University Ago-Iwoye. $13^{\text {th }}$ November, 2001: 1-8.

10 Anon Agricultural Development in Nigeria 1973-1985 Federal Department of Agriculture Lagos 1994.

11 Orvini AO Survey of Cocoyam Production and Consumption in Ijebu North Local Government Area of Ogun State. Nigeria. A PGDEX project in the Department of Agricultural Extension and Rural Sociology. Ogun State University. Ago- Iwoye. 89pp 1997. 
12 Ogunyanwo OA Improving The Nutrient Quality Of An Ijebu Dish-Ebiripo and Comparing With Another Ijebu Dish-Ikokore”. An M.Sc Dissertation in the Department of Human Nutrition College of Medicine, University of Ibadan, Ibadan Nigeria.102pp.1982.

13 Ogundahunsi GA Estimation of Digestive Energy of Cocoyam foods: (i) Roasted (ii) Peeled and boiled (iii) Peeled, ground and steamed” $A n$ M.Sc.Dissertation in the Department of Human Nutrition, College of Medicine, University of Ibadan, Ibadan Nigeria.105pp. 1981.

14 Agbelemoge A Socio-cultural determinants of cocoyam (Colocasia and Xanthosoma spp) utilization at household level in southwestern Nigeria. A $\mathrm{PhD}$ Thesis. Department of Agricultural Extension and Rural Development, College of Agricultural Management, Rural Development and Consumers Studies, University of Agriculture, Abeokuta. Nigeria.202pp 2003.

15 Statistical Package for Social Sciences, Inc SPSS Base 7.0 Application Guide, Prentice Hall, Chicago.USA 214p.1996.

16 Nyiira $\mathbf{Z} \mathbf{M}$ Technological Change in Indigenous Root and Tuber Crop Production Systems in Sub-Sahara Africa. Proceeding of the $5^{\text {th }}$ Symposium of ISRTC African Branch 1994: 50-55.

17 Fishbein $\mathbf{M}$ and I Ajzen Belief, Attitude, Intention and Behavior: The Introduction of Theory and Research. Addision-Wesley Reading MA 1975. 